\title{
IMPLEMENTATION OF COMPREHENSIVE MIDWIFERY CARE
}

\author{
By \\ Netty Herawaty Purba ${ }^{1}$, Septi Maisyaroh Ulina Panggabean ${ }^{2}$, Masriani Situmorang ${ }^{3}$ \\ 1,2,3 STIKes Awal Bros Batam \\ Email: ${ }^{1}$ nettyoerba21@ gmail.com, ${ }^{2}$ Septi.panggabean190989@ gmail.com, \\ 3.Masrianisitumorang23@gmail.com
}

\begin{abstract}
Article Info
Article history:

Received May 10, 2021

Revised June 22, 2021

Accepted July 21, 2021

Keywords:

Comprehensive Midwifery Care

ABSTRACT

The research aims: To provide comprehensive midwifery services to mothers since pregnancy, childbirth, newborns and contraception services. Research methods: The research design used is descriptive, with a clinical case study method.

Research result: From the results of the assessment of Mrs. M aged 23 and the comprehensive midwifery care that had been given and it was found that everything was in normal condition. After doing Comprehensive Midwifery Care at Independent Practice Midwives/ BPM Nurkhairiyah, comprehensive midwifery care has been given. The client says he is satisfied and understands the care he has received, and provides great benefits for the client and the baby and family and for the client in providing family planning care, the client has not decided to choose a contraceptive will be used..

Conclusion: From the midwifery care obtained, the mother said she felt satisfied and appreciated, both in the care of pregnancy, childbirth, postpartum, newborn and the period of choice of using contraception. the mother feels that she can play a role in making choices regarding needs as well as in decision making.

Suggestion: Midwives should be able to carry out comprehensive care on an ongoing basis so that in the hope of reducing maternal and infant mortality and morbidity, it can be achieved.
\end{abstract}

This is an open access article under the CC BY-SA license.

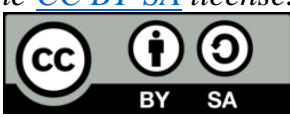

Corresponding Author:

Netty Herawaty Purba

STIKes Awal Bros Batam

Email: nettyoerba21@gmail.com

\section{INTRODUCTION}

According to the Chair of the Scientific Committee of the International Conference on Indonesia Family Planning and Reproductive Health (ICIFPRH), until 2019 Indonesia's Maternal Mortality Rate (MMR) is still high, at 305 per 100,000 live births. In fact, the target for Indonesia's MMR in 2015 is 102 per 100,000 live births. The high MMR is one of the challenges that must be faced by Indonesia so that it becomes one of the national priority commitments, namely reducing maternal mortality during pregnancy and childbirth (Podungge, 2020).

One of the efforts that can be done to reduce MMR is suggested that health workers are expected to prevent obstetric and neonatal complications, such as asphyxia, congenital abnormalities, other co-morbidities in infants and hypertension in pregnancy and the puerperium. When pregnant women are monitored closely, namely by conducting timely and complete Antenatal Care (ANC) for pregnant women including giving Fe (iron) tablets to mothers and monitoring them through maternal and child health surveillance officers(Kusumawardani \& Handayani, 2018). 
Comprehensive care, namely midwifery management starting from pregnant women, giving birth, to newborns so that childbirth can take place safely and babies born are safe and healthy until the puerperium. Continuing care related to health professionals, midwifery services is carried out starting from preconception, early pregnancy, during all trimesters, birth, until the first 6 weeks postpartum. The aim is to assist efforts to accelerate the decline in MMR (Homer, 2016).

Comprehensive midwifery care is to provide midwifery care with reference to care in which women are the center since pregnancy in a sustainable and comprehensive manner. The provision of women-centered care is also applied by midwifery students with the aim that students can learn from clients intensively because we know that each has different needs and thus has a different plan of care (Fastabiq, 2017).

Efforts to accelerate the decline in MMR can be done by ensuring that every mother is able to access quality maternal health services, such as health services for pregnant women, delivery assistance by two trained health workers in health care facilities, postnatal care for mothers and babies, special care and referrals if needed. complications occur, it is easy to get maternity and maternity leave and family planning services, as an effort to reduce MMR and IMR. The SDGs (Sustainable Development Goals) program is a program, one of which is to have a target to reduce MMR and IMR. The SDGs have a target to reduce the MMR, which is less than 70 per 100,000 KH by 2030 and try to reduce the IMR at least to 12 per $1000 \mathrm{KH}$ (WHO, 2015).

Based on reported maternal deaths, the Maternal Mortality Rate (MMR) of Riau Islands Province in 2018 was 98 per 100,000 live births (41 maternal deaths / 41,689 live births multiplied by a constant 100,000). The MMR achievement in 2018 was better than the MMR in 2017 which was 120 per 100,000 live births. Based on the number of maternal deaths, there was also a decrease from 51 cases of maternal mortality in 2018, down to 41 cases in 2019(Riskesdas Provinsi Riau, 2018).

Based on health service reports, the IMR in the Riau Islands Province in 2018 was 6.4 per 1,000 live births. This figure can be said to be very low when compared to IMR data from surveys such as the National IMR data based on the 2017 Indonesian Demographic and Health Survey (IDHS) which is 32 per 1,000 live births and the National IMR data based on the results of the Inter-Census Population Survey (SUPAS) in 2017. 2015 which was 22.23 per 1,000 live births (Riskesdas Provinsi Riau, 2018).

Secondary data obtained from PMB (Independent Midwife practice) Nurkhoiriyah Batu Aji Batam City in the last two years 2018-2020, the number of Maternal Mortality Rate is 0 people, Infant Mortality Rate is 0 people, the number of visits by pregnant women is 500 people, who perform $\mathrm{K} 1$ as many as 300 people and $\mathrm{K} 4$ as many as 380 people, 460 people giving birth, 443 people postpartum, family planning acceptors as many as 715 people. The midwife stated that comprehensive care in the local area had not been maximally carried out (Black, 2016).

\section{LITERATURE REVIEW AND HYPOTHESES DEVELOPMENT}

\section{Comprehensive Midwifery Care}

Comprehensive midwifery care is care provided by midwives to mothers from the time of pregnancy, childbirth, newborn, postpartum and family planning. The aim is to provide quality services to prevent maternal and child mortality. The role and function of the midwife is very helpful in the comprehensive care process through supervision of assistance, supervision of pregnancy, childbirth, newborns, postpartum and family planning (Yulita, 2019).

A risk approach that has a rationalization that careantenatal care is to perform screening to predict risk factors for predict a disease. Research results showing that $71 \%$ obstructed labor is unpredictable, $90 \%$ of mothers identified as having the risk of never complications and $88 \%$ of women who experience postpartum haemorrhage has no predictive history. The risk approach has a worse predictive value, therefore unable to distinguish those who will experience and those who experience complications, also false safety because many mothers are included in low risk experienced complications, but they never received information about complications pregnancy and how to treat it (Kuruvilla, 2014).

The nature of women as a mother to go through the process that. A woman will go through several natural processes, starting from pregnancy, childbirth, postpartum, the presence of a newborn and use of contraception to prepare for family planning.

\section{ANC (Ante Natal Care)}

The World Health Organization (WHO) envisions a world where every pregnant woman and newborn receives quality care throughout the pregnancy, childbirth and the postnatal period. Within the continuum of reproductive health care, antenatal care (ANC) provides a platform for important health-care functions, including health promotion, screening and diagnosis, and disease prevention . 
International Journal of Social Science (IJSS)

Vol.1 No.2 August 2021, pp: 79-84

ISSN: 2798-3463 (Printed) | 2798-4079 (Online)

DOI: https://doi.org/10.53625/ijss.v1i2.139

Antenatal care (ANC) can be defined as the care provided by skilled health-care professionals to pregnant women and adolescent girls in order to ensure the best health conditions for both mother and baby during pregnancy. The components of ANC include: risk identification; prevention and management of pregnancy-related or concurrent diseases; and health education and health promotion (Blencowe, 2015).

The ANC visit service is used as an indicator of the coverage of the first visit of pregnant women who check their pregnancy to health workers at least 1 time in the first trimester (ideal K1) and the coverage of visits by pregnant women who check their pregnancy to health workers at least 4 times according to criteria 1-1-2 (at least 1 times in the 1st trimester, at least 1 time in the 2nd trimester, at least 2 times in the 3rd trimester or also called K4 (Kementerian Kesehatan RI, 2013).

3. Childbirth

Normal labor is the process of expelling the products of conception (fetus and uri) who have reached term and can live outside the uterus through the vagina spontaneously spontaneous (Sarwono, 2019).

Clinically, it can be stated that parturition begins when his is present and the woman, It secretes mucus accompanied by blood (bloody show). The slime accompanied by blood comes from cervical canal mucus because the cervix begins to open or horizontal. While the blood comes from the veins. The capillaries around the cervical canal rupture due to shifts when the cervix opens (Bauserman, 2015).

\section{Postpartum}

The puerperal period (puerperium) is a period of 6-8 weeks after delivery. This process begins after the completion of labor and ends after the reproductive organs return to their previous state pregnant/non-pregnant as a result of physiological changes and psychology of childbirth (Of, 2018).

Postpartum (puerperium) is the period that begins after the placenta comes out and ends when the uterine organs recover as before. During the recovery period, the mother will undergo many physical changes that are physiological and many provide discomfort in the early postpartum, which does not close likely to become pathological if not followed by treatment the good one (Homer, 2016).

5. Family Planning

Reproductive health is a state of complete physical, mental and social well-being intact, not merely free from disease or disability in a related with the reproductive system, its functions and processes.

Government regulation Number 61 of 2014 on Reproductive Health which guarantees. Everyone has the right to obtain quality, safe and secure reproductive health services accountable, where this regulation also guarantees women's health in the reproductive age so as to be able to give birth to a healthy, high-quality generation will have an impact on reducing maternal mortality (Peraturan Pemerintah (PP), 2014).

The concept of Reproductive Health uses a women's life cycle approach (life-cycle-approach) or reproductive health services are carried out from the fetus to the grave (from womb to tomb) or also known as "Continuum of care" women cycle". Reproductive health uses a life cycle approach. This is due to the health status of women during childhood and adolescence affect health conditions when entering the reproductive period, namely during pregnancy, childbirth, and the puerperium (Medhanyie, 2012).

\section{METHOD}

This research method is is a descriptive analysis with a clinical case study approach from pregnancy to family planning services. The research design used is descriptive type, in the form of research with a case study method or approach. Data collection first with Observation Observations were made directly on the respondent's assessment then conducted interviews conducted directly between the researcher and the respondent which led to problem solving. After the interview, a physical examination was carried out using inspection, palpation, aulcutation and percussion techniques. After that, Documentation is done. Data collection from events documented by the SOAP method and for publication. Data Analysis Comprehensive care data analysis from the data collection process that was compiled systematically and analyzed, and identified according to the SOAP method approach. The respondents used were pregnant women in the third trimester (34-40 weeks) by paying attention to comprehensive care ranging from Pregnant Women, Maternity, Postpartum, Newborns to Family Planning. The location of comprehensive midwifery care is carried out at the Independent Midwife Practice (PMB). The time required in preparing the proposal, conducting midwifery care until the Final Project Report starts from November 2020 to February 2021.

\section{RESULTS AND DISCUSSION}

\section{a. Antenatal Care}

From the results of the assessment, Mrs. M, aged 23, in pregnancy there was a gap that occurred, namely in the Leopold examination. On examination Leopold 1 on the fundus felt hard, round, and bouncy impression of the 
head. On examination Leopold 2 there is a left back. In Leopold 3 at the bottom of the fetus feels soft, round, not bouncy impression of the buttocks. On examination Leopold is found in the lower part of the fetus with a buttocks or breech position.

According to (Sarwono, 2019) Leopold I examination was used to determine the height of the uterine fundus, the part of the fetus in the fundus, and the consistency of the fundus. At the location of the head will be palpable buttocks on the fundus, which is not hard, not bouncy and not round. Leopold II Determines the right / left on the mother's abdomen and determines the location of the back. Longitudinal location can be determined by the child's back, which is palpable firmly. While the parts that seem small are the extremities of the fetus. Leopold III Determines the lower part of the fetus above the mother's symphysis and the lowest part of the fetus has entered the pelvic inlet (PAP) or can still be shaken. Leopold IV Determines the lower part of the fetus and how far the fetus has entered (the pelvic inlet) PAP. If the lowest part of the PAP has crossed its largest circle, then the hand that is doing the examination is divergent, while if the largest circle has not entered the PAP, the examiner's hand is convergent.

In this case Mrs. M could not give birth at an independent clinic because the baby was in a breech position. Due to the condition of the baby in a breech position or the location of the buttocks, if treated in the clinic, complications can occur for the mother and fetus.

Mrs. $\mathrm{M}$ is advised to give birth in a more complete health facility so that it is immediately handled by an obstetrician.

\section{b. Childbirth}

At delivery, a gap was found in Mrs. M, namely opening too quickly. The opening that was too fast was caused by the strong contractions in Mrs. $\mathrm{M}$ and rupture of membranes at dilatation of $4 \mathrm{~cm}$. Factors that affect the first stage is only 1 hour 45 minutes, namely: Mrs. M is too active to move, walk, and multiparity. So that the mother during the first stage of labor only takes 1 hour 30 minutes.

The government's effort to reduce maternal and neonatal mortality is through the MPS (Making Pregnancy Safer) program in which three activities in the program, namely childbirth by trained health personnel, obstetric and neonatal complications, get adequate services and access to WUS (Women of Childbearing Age) related to unprotected pregnancy. It is also undesirable to treat complications of miscarriage (Wagner, 2021).

The management of APN (Normal Birth Care) is an effort to increase the knowledge of midwives as well as skills and attitudes towards decision making in the application of maternal care and the principles of prevention of infection, documentation, and planned referrals in preventing or minimizing maternal and infant morbidity and mortality(Noorbaya et al., 2019).

\section{c. Puerperium}

In the postpartum period, a gap was found in Mrs. M, namely during pregnancy with her second child, Mrs. M doesn't come out. Here the author performs IMD on newborns. The author also recommends Mrs. M to keep stimulating Mrs. M by continuing to breastfeed the baby even though the milk doesn't come out. This can make the hormone prolactin stimulated from the baby's sucking and there is a lot of milk production for the baby. So that on the 2nd post-delivery day, the mother's milk is smooth and there is milk expulsion. In post-delivery, the author provides care according to the mother's needs, namely informing the mother that the mother is in good condition, explaining to the mother that the uterus is in good condition and teaching uterine massage techniques, telling the mother to do early mobilization such as tilting to the right and tilting to the left then slowly sitting up and start bathing myself. Inform the mother of danger signs during the puerperium such as heavy vaginal bleeding $2 \mathrm{x}$ change of pads in hour, discharge of a strong odor, severe headache, swelling of the face or in the hands and feet, fever, red and hot breasts, feel pain.

The management of care for mothers during the puerperium must provide a lot of counseling such as personal hygiene, rest, gradual exercise, nutrition, breast care, intercourse, breastfeeding contraception and exclusive breastfeeding (Kementerian Kesehatan RI, 2013).

\section{d. Newborn}

Newborn cares, baby. Mrs. M was born spontaneously at 09.00 WIB. From the anamnesis of the newborn regarding health, the birth history was born on January 25, 2021 at 09.00 WIB with a gestational age of 39 weeks and 3 days, male sex, strong crying, positive muscle tone (+), reddish skin color, anus ( +), with an APGAR score of 9/10.

From the results of the examination carried out on the baby, Mrs. M found that the baby's weight Mrs. M of 3500 grams, it shows that the baby's weight Mrs. M is normal. In accordance with the characteristics of a normal newborn according to (Sarwono, 2019)that the weight of a normal newborn is in the range of 2500-4000 grams. The length of the baby Mrs. S is $50 \mathrm{~cm}$, and the length of the newborn is normal. The birth weight and length of the baby is an indicator of the status of the baby's growth and development. The problem of the size of the baby, both the weight and length of the baby is an assessment that can be seen since the mother carried out an antenatal examination with an abdominal examination and anamnesis related to the nutritional status and health of the mother (Kusumawardani \& Handayani, 2018). Other anthropometric examinations that were examined were head circumference and chest 
International Journal of Social Science (IJSS)

Vol.1 No.2 August 2021, pp: 79-84

ISSN: 2798-3463 (Printed) | 2798-4079 (Online)

DOI: https://doi.org/10.53625/ijss.v1i2.139

circumference, from the examination the baby Mrs. M has a head circumference of $34 \mathrm{~cm}$ and a chest circumference of $32 \mathrm{~cm}$, the results of the examination showed that the baby Mrs. M is normal because according to the theory that the head circumference and chest circumference of a normal newborn are $33-35 \mathrm{~cm}$, and $30-38 \mathrm{~cm}$. Based on the examination, it was found that Mrs. M under normal conditions, this is in accordance with the theory that normal heart sounds are 120-160 beats/minute, breathing in the first minute is about 40-60 breaths/minute, skin is reddish, smooth and covered with vernix caseosa, lanugo hair is not visible, the head hair is usually perfect, the nails are a bit long and limp, the testicles have descended on the genitals and various reflexes have looked good. Anthropometric examination of BBL can be done immediately after the baby is born. The size of the anthropometric examination can also be done as one of the detection of abnormalities in newborns, for example the size of the head that is too small or larger than the normal size (Sukamti \& Riono, 2015). Baby Mrs. M was given 1\% Oxytetracycline eye ointment on both eye conjunctiva, which is useful for preventing transmission of infection from mother to baby (Rini \& Yusran, 2017). The author also gave vitamin $\mathrm{K}$ after 1 hour of delivery to the left outer $1 / 3$ of the thigh. According to the theory, all newborns should be given vitamin $\mathrm{K}$ to prevent bleeding in the brain due to vitamin $\mathrm{K}$ deficiency which can be experienced by some newborns. According to the Ministry of Health guidelines, the latent phase lasts for 8 hours and the active phase is about 6 hours. Stage II lasts 1 hour. The third stage lasts at most 30 minutes. The fourth stage was observed for 2 hours from the delivery of the placenta.

\section{e. Family Planning}

Mrs. M had never used contraception before. From the author's counseling explanation, it has been found that Mrs. M wants to use KB, he wants to use 3-month injection KB. The author recommends using KB Implant but the mother is afraid to use the KB. Mrs. M will still communicate or decide on the use of family planning that she will use with her husband.

Explain in advance to the mother about the purpose of family planning, so that if the mother already knows her goals in family planning, she can choose the appropriate contraception. This is explained in accordance with the theoretical basis for the purpose of family planning, including: preventing unwanted pregnancies, seeking desired births, limiting the number of children in the family, maintaining a good distance between births.

The Lactational Amenorrhea Method (MAL) is a contraceptive that relies on exclusive breastfeeding, meaning that it is only given breast milk without any additional food or drink. Passive immunity is obtained by infants who are obtained from breast milk, where breast milk is a protective antibody for infants. Can make baby growth and development perfect and optimal, provide good nutritional intake for babies, avoid exposure to contamination from other milk or formula milk or drinking utensils used (Kurniawati, 2017).

\section{CONCLUSION}

Conclusion of this research it was found that the mother had regular ANC visits, and complaints during pregnancy could be handled well. for the delivery process also went normally without complications as well as the baby was born normally the baby's condition was fit, there were no complications, and the postpartum period also went normally. For contraceptive services, the mother chooses to use the lactational amenorrhoea method because the mother will breastfeed the baby until the age of 6 months. and in addition the mother's lactation process also runs smoothly.

From the midwifery care obtained, the mother said she felt satisfied and appreciated, both in the care of pregnancy, childbirth, postpartum, newborn and the period of choice of using contraception. the mother feels that she can play a role in making choices regarding needs as well as in decision making.

\section{REFERENCES}

[1] Bauserman, M., Lokangaka, A., Thorsten, V., Tshefu, A., Goudar, S. S., Esamai, F., Garces, A., Saleem, S., Pasha, O., Patel, A., Manasyan, A., Berrueta, M., Kodkany, B., Chomba, E., Liechty, E. A., Michael Hambidge, K., Krebs, N. F., Derman, R. J., Hibberd, P. L., ... Bose, C. L. (2015). Risk factors for maternal death and trends in maternal mortality in low- and middle-income countries: A prospective longitudinal cohort analysis. In Reproductive Health. https://doi.org/10.1186/1742-4755-12-S2-S5

[2] Black, R. E., Walker, N., Laxminarayan, R., \& Temmerman, M. (2016). Reproductive, Maternal, Newborn, and Child Health: Key Messages of This Volume. In Reproductive, Maternal, Newborn, and Child Health: Disease Control Priorities, Third Edition (Volume 2).

[3] Blencowe, H., Cousens, S., Jassir, F. B., Say, L., Chou, D., Mathers, C., Hogan, D., Shiekh, S., \& Qureshi, Z. U. (2015). National, regional, and worldwide estimates of stillbirth rates in 2015, with trends from 2000 : a systematic analysis. The Lancet Global Health, 4(2), e98-e108. https://doi.org/10.1016/S2214-109X(15)002752 
[4] Fastabiq, F. (2017). PENGARUH PROGRAM OSOC (ONE STUDENT CLIENT) TERHADAP KETERAMPILAN MAHASISWA BIDAN DALAM MEMBERIKAN ASUHAN KEBIDANAN. Jurnal Imu Kesehatan.

[5] Homer, C. S. E. (2016). Models of maternity care: Evidence for midwifery continuity of care. Medical Journal of Australia. https://doi.org/10.5694/mja16.00844

[6] Kementerian Kesehatan RI. (2013). Pelayanan Kesehatan Ibu di Fasilitas Kesehatan Dasar dan Rujukan. Pedoman Bagi Tenaga Kesehatan. Kementerian Kesehatan RI.

[7] Kurniawati, N. (2017). Peran Dukungan Suami pada Keberhasilan Metode Amenore Laktasi (MAL) di Puskesmas Bayan Kecamatan Bayan Kabupaten Purworedjo. Jurnal Komunikasi Kesehatan.

[8] Kuruvilla, S., Schweitzer, J., Bishai, D., Chowdhury, S., Caramani, D., Frost, L., Cortez, R., Daelmans, B., de Francisco, A., Adam, T., Cohen, R., Alfonso, Y. N., Franz-Vasdeki, J., Saadat, S., Pratt, B. A., Eugster, B., Bandali, S., Venkatachalam, P., Hinton, R., ... Bustreo, F. (2014). Success factors for reducing maternal and child mortality. Bulletin of the World Health Organization. https://doi.org/10.2471/BLT.14.138131

[9] Kusumawardani, A., \& Handayani, S. (2018). Karakteristik Ibu dan Faktor Risiko Kejadian Kematian Bayi di Kabupaten Banjarnegara. Jurnal Promosi Kesehatan Indonesia. https://doi.org/10.14710/jpki.13.2.168-178

[10] Medhanyie, A., Spigt, M., Kifle, Y., Schaay, N., Sanders, D., Blanco, R., Geertjan, D., \& Berhane, Y. (2012). The role of health extension workers in improving utilization of maternal health services in rural areas in Ethiopia: A cross sectional study. BMC Health Services Research. https://doi.org/10.1186/1472-6963-12-352

[11] Noorbaya, S., Johan, H., \& Reni, D. P. R. (2019). Studi Asuhan Kebidanan Komprehensif di Praktik Mandiri Bidan yang Terstandarisasi APN. Husada Mahakam: Jurnal Kesehatan. https://doi.org/10.35963/hmjk.v4i7.149

[12] Of, B., Care, C., For, C., \& Of, M. (2018). Jurnal Kesehatan Masyarakat BENEFIT OF CHILDBIRTH CARE COUNSELING FOR MOOD OF POSTPARTUM. 13(63), 356-365.

[13] Podungge, Y. (2020). ASUHAN KEBIDANAN KOMPREHENSIF. Jambura Health and Sport Journal. https://doi.org/10.37311/jhsj.v2i2.7102

[14] Rini, A. S., \& Yusran, M. (2017). Oftalmia Neonatorum et Causa Infeksi Gonokokal. Majority Unila.

[15] Riskesdas Provinsi Riau. (2018). Profil kesehatan. Dinas Kesehatan Provinsi Riau. Tahun 2018. Profil Kesehatan. Dinas Kesehatan Provinsi Riau.

[16] Sarwono, P. (2019). Ilmu Bedah Kebidanan. Journal of Chemical Information and Modeling.

[17] Sukamti, S., \& Riono, P. (2015). Pelayanan Kesehatan Neonatal Berpengaruh Terhadap Kematian Neonatal di Indonesia (Analisis Data Riskesdas 2010). Jurnal Ilmu Dan Teknologi Kesehatan.

[18] Umum, K. (2014). No Title.

[19] Wagner, G. J., Mindry, D., Hurley, E. A., Beyeza-Kashesya, J., Gwokyalya, V., Finocchario-Kessler, S., Wanyenze, R. K., Nanfuka, M., Tebeka, M. G., \& Goggin, K. (2021). Reproductive intentions and corresponding use of safer conception methods and contraception among Ugandan HIV clients in serodiscordant relationships. BMC Public Health. https://doi.org/10.1186/s12889-021-10163-7

[20] WHO. (2015). HEALTH IN 2015: FROM MDGs TO SDGs. In Harvard International Review.

[21] Yulita, N., Juwita, S., \& Indonesia, R. (2019). Analisis Pelaksanaan Asuhan Kebidanan Komprehensif (Continue Of Care/COC) Di Kota Pekanbaru. JOMIS (Jurnal Of Midwifery Science). 